\title{
Pendokumentasian Asuhan Keperawatan Berbasis Komputer
}

\author{
Natasia Atania Sitepu \\ natasiaatania2@gmail.com
}

\section{Latar Belakang}

Teknologi informasi merupakan hal yang tidak dapat dihindari di jaman yang sangat modern ini. Peranan teknologi pada aktivitas manusia saat ini memang begitu besar. Berkat teknologi berbagai kemudahan dapat dirasakan oleh manusia. Hal tersebut akan juga berpengaruh pada keinginanan masyarakat untuk mendapatkan pelayanan kesehatan yang bermutu dengan adanya kemajuan teknologi.

Perkembangan teknologi kesehatan di dunia, kesehatan tidak lepas dari teknologi digital dan internet, kemajuan teknologi yang begitu pesat berdampak juga pada bidang kesehatan. Pelayanan keperawatan merupakan pelayanan profesional dan memegang peranan penting dalam upaya menjaga dan meningkatkan mutu pelayanan dirumah sakit karena pelayanan keperawatan tersedia selama 24 jam secara berkelanjutan.

Tenaga perawat sebagai salah satu tenaga yang mempunyai kontribusi besar bagi pelayanan kesehatan, mempunyai peranan penting untuk meningkatkan mutu pelayanan kesehatan. Dalam upaya meningkatkan mutu pelayanan kesehatan, seorang perawat harus mampu melaksanakan asuhan keperawatan sesuai standar, yaitu dari mulai pengkajian sampai dengan evaluasi dan yang sangat penting adalah disertai dengan sistem pendokumentasian yang baik. Namun pada realitanya dilapangan, asuhan keperawatan yang dilakukan masih bersifat manual dan konvensional, belum disertai dengan sistem /perangkat tekhonolgi yang memadai. Contohnya dalam hal pendokumentasian asuhan keperawatan masih manual, sehingga perawat mempunyai potensi yang besar terhadap proses terjadinya kelalaian dalam praktek. Dengan adanya kemajuan teknologi informasi dan komunikasi, maka sangat dimungkinkan bagi perawat untuk memiliki sistem pendokumentasian asuhan keperawatan yang lebih baik dengan menggunakan Sistem Informasi Manajemen. 
Dokumentasi merupakan salah satu komponen penting yang dapat memberikan kesaksian hukum, dokumentasi keperawatan menjadi alat komunikasi dan sumber edukasi serta sumber riset. Pendokumentasian asuhan keperawatan secara akurat dan berkesinambungan adalah salah satu kewajiban perawat. Hal ini diatur dalam Peraturan Menteri Kesehatan Nomor 148 tahun 2010 tentang izin dan penyelenggaraan praktik perawat, dalam pasal 12 ayat 1, disebutkan bahwa perawat berkewajiban melakukan pencatatan asuhan keperawatan secara sitematis, dan memenuhi standar.

Pendokumentasian asuhan keperawatan sangat penting namun pada implementasinya sering kali diabaikan/tidak dipatuhi sehingga kelengkapan, ketepatan, kualitas dan relevansi antar proses dokumentasi keperawatan masih menjadi temuan. Pendokumentasian juga merupakan alat pengendalian yang dapat mengukur kualitas pelayanan keperawatan, walaupun pengendalian bersifat tidak langsung tetapi gambaran kualitas dokumentasi dapat memotret kualitas pelayanan secara umum.

Dokumentasi keperawatan sering ditemukan tidak lengkap dan tidak dapat dibenarkan dan bahkan cenderung diabaikan karena dalam menyelesaikan dokumentasi asuhan keperawatan memerlukan banyak waktu untuk menulis sehingga untuk mengambil waktu perawat dalam asuhan keperawatan. Berdasarkan permasalahan tersebut oleh karena itu penulis mengangkat judul "Pendokumentasian Asuhan Keperawatan Berbasis Komputer"

\section{Metode}

Metode yang digunakan dalam penulisan ini adalah metode kualitatif yang dimana penulis mengumpulkan data sebanyak-banyaknya untuk dianalisis. Tulisan ini didasarkan dengan menganalisis berbagai jurnal atau karya tulis ilmiah yang berfokus pada "Pendokumentasian Asuhan Keperawatan Berbasis Komputer". Adapun tinjauan literatur yang digunakan dalam penulisan ini menggunakan metode kajian bebas terhadap pokok bahasan yang dikumpulkan dari jurnal atau karya tulis ilmiah yang bersal dari E-book atau Google Scholar. Pengolahan ini dilakukan dengan metode membandingkan beberapa jurnal atau karya tulis ilmiah yang digunakan dan berhubungan dengan pendokumentasian asuhan keperawatan berbasis komputer. 


\section{Hasil}

Perkembangan pengetahuan dan teknologi membuat orang berpikir lebih kritis, termasuk dalam penggunaan layanan kesehatan, oleh karena itu perawat sebagai salah satu petugas kesehatan diwajibkan untuk melakukan dokumentasi yang baik tentang asuhan keperawatan agar ketika ada masalah yang muncul antara pasien dan perawat, dokumentasi dapat digunakan sebagai bukti otentik yang dapat melindungi perawat dan pasien. Menulis dokumentasi yang akurat dan lengkap memudahkan perawat untuk mengidentifikasi masalah sehingga mereka dapat memberikan intervensi yang sesuai dengan masalah yang dihadapi oleh pasien dan secara tidak langsung akan meningkatkan mutu layanan perawatan. Perkembangan teknologi ini perannya dapat membangun mutu perawatan kesehatan yang lebih baik karena dapat membantu para dokter dan praktisi kesehatan (Sutoto, 2019).

Sistem informasi manajemen berbasis komputer sudah mulai banyak digunakan di lingkungan kesehatan, terutama di bidang keperawatan. Strategi pengembangan teknologi komputer untuk pendidikan keperawatan adalah penggunaan simultan keperawatan virtual. Sistem informasi manajemen di Indonesia masih mengalami banyak kendala. Di luar Indonesia, teknologi telah banyak membantu manajemen pendidikan keperawatan, khususnya penggunaan komputer dalam asuhan keperawatan. Komputer ini didasarkan pada tiga dimensi, dengan bekerja untuk mensimulasikan pengalaman pasien seolah-olah itu nyata dan dalam lingkungan yang bebas risiko, di mana ada sesi pelatihan hingga pengambilan keputusan klinis dengan beragam kondisi pasien, dan segera memberikan umpan balik. Di Indonesia, proses menggunakan komputer dalam dokumentasi keperawatan sangat lambat, sehingga perlu menyegarkan aplikasi sistem informasi keperawatan untuk pengembangan pendidikan keperawatan. (Prasetyanto, D., Sukihananto, 2019).

Sesuai dengan penelitian Dewi, pengembangan dokumentasi keperawatan elektronik berbasis teknologi informasi yang memberikan manfaat bagi perawat, antara lain: waktu dokumentasi menjadi lebih pendek, kemudahan membaca dan mengakses dokumen dan memungkinkannya sebagai alat pembelajaran (Dewi, 2010). Dengan terlaksananya dokumentasi ini tidak lagi menggunakan kertas laporan atau buku yang berlembar-lembar jumlahnya tetapi cukup hanya dengan melihat pada layar komputer sudah dapat melihat keseluruhan data pasien. 


\section{Pembahasan}

Dokumentasi asuhan keperawatan adalah catatan tentang kesehatan pasien yang jelas dan sistematis, meliputi pengkajian, diagnosa, perencanaan, pelaksanaan dan evaluasi selama proses perawatan, yang dilakukan oleh perawat sebagai bentuk tanggung jawab atas tugas yang telah dilaksanaknnya dalam meningkatkan mutu pelayanan keperawatan dan pelayanan kesehatan.

Manfaat dokumentasi dilihat dari berbagai aspek seperti aspek hukum, kualitas pelayanan, komunikasi, keuangan, pendidikan, penelitian, dan akreditasi. Penjelasan mengenai aspek-aspek tersebut adalah sebagai berikut:

1. Hukum

Bila menjadi suatu masalah (misconduct) yang berhubungan dengan profesi keperawatan, dimana sebagai pemberi jasa dan klien sebagai pengguna jasa, maka dokumentasi dapat dipergunakan sewaktu-waktu. Dokumentasi tersebut dapat dipergunakan sebagai barang bukti di pengadilan.

2. Kualitas Pelayanan

Untuk mengetahui sejauh mana masalah klien dapat teratasi dan seberapa jauh masalah dapat diidentifikasi dan dimonitor melalui dokumentasi yang akurat. Hal ini akan membantu meningkatkan kualitas (mutu) pelayanan keperawatan, dan mutu pelayanan kesehatan.

\section{Komunikasi}

Perawat atau profesi kesehatan lain dapat melihat dokumentasi yang ada dan sebagai alat komunikasi yang dijadikan pedoman dalam memberikan asuhan keperawatan.

\section{Keuangan}

Semua asuhan keperawatan yang belum, sedang, dan telah diberikan didokumentasikan dengan lengkap dan dapat dipergunakan sebagai acuan atau pertimbangan dalam biaya keperawatan bagi klien.

5. Pendidikan

Karena isinya menyangkut kronologis dari kegiatan asuhan keperawatan yang dapat dipergunakan sebagai bahan atau referensi pembelajaran bagi peserta didik atau profesi keperawatan.

6. Penelitian 
Data yang terdapat didalamnya mengandung informasi yang dapat dijadikan sebagai bahan atau objek riset dan pengembangan profesi keperawatan.

7. Akreditasi

Melalui dokumentasi keperawatan akan dapat dilihat sejauh mana peran dan fungsi perawat dalam memberikan asuhan keperawatan kepada klien. Dengan demikian dapat diambil kesimpulan mengenai tingkat keberhasilan pemberian asuhan keperawatan yang diberikan guna pembinaan dan pengembangan lebih lanjut.

Sistem Informasi Manajemen Rumah Sakit adalah sebuah sistem komputer yang memproses dan mengintegrasikan seluruh alur proses bisnis layanan kesehatan dalam bentuk jaringan koordinasi, pelaporan dan prosedur administrasi untuk memperoleh informasi secara cepat, tepat dan akurat. Saat ini Sistem Informasi Manajemen (SIM) berbasis komputer rumah sakit (SIMRS) merupakan sarana pendukung yang sangat penting, bahkan bisa dikatakan mutlak untuk mendukung pengelolaan operasional rumah sakit (Ammenwerth, at al, 2011)

Sistem informasi keperawatan adalah kombinasi dari ilmu komputer, ilmu informasi, dan ilmu keperawatan yang dirancang untuk membantu manajemen dan proses data keperawatan, informasi, dan pengetahuan untuk mendukung praktik keperawatan dan pemberian perawatan (Hariyati, Kobayashi, \& Sahar, 2018).

Sistem Informasi Keperawatan (NIS) adalah bagian dari sistem informasi perawatan kesehatan yang berhubungan dengan aspek keperawatan, terutama pemeliharaan catatan keperawatan. Beberapa tujuan yang harus dipenuhi oleh sistem informasi keperawatan untuk mencapai tujuannya, memenuhi kebutuhan pengguna dan beroperasi dengan baik dijelaskan. Fungsi sistem tersebut, yang dikombinasikan dengan tugas-tugas dasar proses asuhan keperawatan.

Dokumentasi keperawatan berbasis komputerisasi dibuat untuk membantu manajemen dan proses data keperawatan, informasi, dan pengetahuan untuk mendukung praktik keperawatan dan pemberian perawatan.

Dokumentasi asuhan keperawatan berbasis komputer adalah pencatatan yang dilakukan dengan menggunakan perangkat computer yang telah disediakan perangkat lunak sesuai dengan kebutuhan. Pemasukan data dilakukan setiap saat sehingga perkembangan pasien dapat terekam secara kontinyu dan komprehensif. 
Dengan sistem dokumentasi yang berbasis komputer pengumpulan data dapat dilaksanakan dengan cepat dan lengkap. Data yang telah disimpan juga dapat lebih efektive dan dapat menjadi sumber dari penelitian, dapat melihat kelanjutan dari edukasi ke pasien, melihat epidemiologi penyakit serta dapat memperhitungkan biaya dari pelayanan Kesehatan (Liaw,T. 1993). Dokumentasi keperawatan dengan menggunakan komputer seyogyanya mengikuti prinsip-prinsip pendokumentasian, serta sesuai dengan standar pendokumentasian internasional seperti: ANA, NANDA, NIC (Nursing Interventions Classification, 2000).

Komputer untuk memasukkan data merupakan komponen yang penting sehingga semua komponen yang tercakup didalamnya bisa tersambung langsung dan bisa dilihat dari bagian manapun. Dokumentasi catatan klinik mencakup hasil pengkajian pasien, laporan keadaan klinik seperti catatan pemberian obat, implementasi yang sudah dilakukan.

Dalam pelaksanaan dokumentasi ini ada berbagai cara yang dilakukan antara lain langsung menuliskan dokumentasi setelah tindakan, menuliskan terlebih dahulu pada lembaran kertas, menuliskan dahulu pada buku catatan kecil, menulis dulu pada tisu toilet dan setelah itu baru memindahkan ke dokumentasi EHR sehingga dalam hal ini ada yang melakukan pencatatan lebih dari satu kali. Hal yang disukai perawat dengan dokumentasi EHR adalah pencatatan tentang pemberian obat, tandatanda vital, pengkajian data dan catatan perkembangan pasien. Tidak semua perawat melakukan pencatatan langsung didekat pasien karena ruang perawatan pasien yang kecil dan Komputer yang yang tidak adekuat (komputer lambat dan memori tidak cukup). Perilaku perawat terhadap dokumentasi secara elektronik didapatkan hasil perilaku perawat sangat menerima karena menurunkan beban kerja dibandingkan menulis dalam catatan kertas sehingga waktu lebih banyak untuk melakukan aktifitas keperawatan.

Kelebihan dan Kekurangan Dokumentasi keperawatan yang dilakukan pada kertas merupakan catatan yang memerlukan waktu dalam hal menulis. Kegiatan ini mulai dari hal penegakan diagnosis keperawatan, penentuan intervensi dan tindakan keperawatan ini disebabkan karena kurangnya kemampuan perawat dalam hal melakukan analisa. Hal ini juga sulit dianalisis untuk. keperluan penelitian dan mendukung proses pengambilan keputusan klinis. Namun pada dokumentasi berbasis komputerisasi dapat membantu perawat untuk mengurangi waktu yang diperlukan dalam proses pendokumentasian sehingga waktu perawat dapat lebih lama kontak 
dengan pasien dalam memberikan asuhan, dapat mengurangi kesalahan dalam melakukan dokumentasi dan evaluasi hasil tindakan keperawatan yang telah diberikan.

Kelebihan dokumentasi berbasis komputerisasi ini adalah kerja perawat lebih efektif, efisien, dan optimal dalam melakukan asuhan keperawatan. Terdapat akurasi, real time, paperless, memudahkan audit tenaga keperawatan. Selain itu asuhan keperawatan lebih terintegrasi, meningkatkan kualitas pelayanan, dan memperluas akses keperawatan (Stubenrauch, 2009).

Penggunaan sistem komputerisasi adalah dapat meningkatkan keselamatan pasien dan kualitas perawatan, meningkatkan penggunaan perencanaan keperawatan sesuai standar, cara anggota tim multidisiplin berinteraksi sesuai dengan standar kualitas hasil dari implementasi EHRs satu sama lain dan klien yang menjadi tanggung jawabnya. Perawat melihat ini sebagai perubahan yang positif, dan perawat merupakan jumlah tenaga terbanyak yang memungkinkan mereka untuk terus memberikan sistem pemberian layanan kesehatan dan harus berada disamping klien setiap saat untuk memberikan perawatan (Mcbride, Delaney, \& Tietze, 2018).

Kelebihan lainnya adalah dapat meningkatkan keamanan sistem perawatan, memungkinkan pertukaran informasi yang lebih dapat diandalkan antara praktisi dan klien dan peningkatan yang signifikan dalam cara perawatan yang akan disampaikan, meningkatkan inisiatif perawat, memasukkan dan mengirimkan implementasi keperawatan yang telah dilaksanakan lebih cepat, dan menciptakan pelayanan yang berpusat kepada pasien (Mcbride et al., 2018).

Kekurangannya adalah butuh anggaran yang besar pada permulaan, akan sangat bergantung pada teknologi, membutuhkan tempat penyimpanan data yang sangat besar, risiko terbukanya kerahasiaan data privacy pasien (Permenkes RI No 82, 2013). Kekurangan lain adalah risiko kemampuan perawat dalam berpikir kritis kurang terasah rumit dengan penggunaan teknologi untuk perawatan pasien, membutuhkan waktu jauh dari perawatan pasien langsung (Mcbride et al., 2018).

\section{Penutup}

Catatan kesehatan elektronik adalah sekumpulan data yang menggambarkan perkembangan tentang kondisi kesehatan seseorang (Weaver et al., 2016). Manfaat yang terkait dengan catatan 
kesehatan elektronik sudah dikenal sejak lama. Evolusi dokumentasi dari kertas ke format elektronik bertujuan untuk selalu meningkatkan komunikasi, mengurangi kesalahan dan memfasilitasi kesinambungan perawatan.

Sistem informasi manajemen berbasis komputer dapat menjadi pendukung pedoman bagi pengambil kebijakan/pengambil keputusan di keperawatan/Decision Support System dan Executive Information System (Eko,I. 2001). Dengan adanya data yang akurat pada keperawatan maka data ini juga dapat digunakan untuk informasi bagi tim kesehatan yang lain. Sistem Informasi asuhan keperawatan juga dapat menjadi sumber dalam pelaksanaan riset keperawatan secara khususnya dan riset kesehatan pada umumnya (Udin,and Martin, 1997). Sistem Informasi manajemen (SIM) berbasis komputer banyak kegunaannya, namun pemanfaatan Sistem Informasi Manajemen di Indonesia masih banyak mengalami kendala.

\section{Daftar Pustaka}

Amalia, A., Malini, H., \& Yulia, S. (2018). Kepuasan Perawat Terhadap Kualitas Pendokumentasian Asuhan Keperawatan Berbasis Komputer. Jurnal Keperawatan Indonesia, 21(3), 169-179.

Atmanto, A. P., Aggorowati, A., \& Rofii, M. (2020). EFEKTIFITAS PEDOMAN PENDOKUMENTASIAN DIAGNOSA DAN INTERVENSI KEPERAWATAN BERBASIS ANDROID TERHADAP PENINGKATAN MUTU DOKUMENTASI KEPERAWATAN DI RUANG RAWAT INAP. Jurnal Keperawatan dan Kesehatan Masyarakat Cendekia Utama, 9(1), 83-92.

Dewi, A., Ningrum, B. S., \& Hariyati, R. T. S. JURNAL SURYA.

Gunawan, G. (2016). Faktor-faktor yang Memengaruhi Penerimaan Perawat Melaksanakan Pendokumentasian Asuhan Keperawatan Berbasis Komputer. Jurnal Pendidikan: Teori, Penelitian, dan Pengembangan, 1(10), 1926-1934.

Putra, A. A., Rejeki, S., \& Kristina, T. N. (2016). Hubungan persepsi perawat tentang karakteristik pekerjaan dengan kepatuhan dalam pendokumentasian asuhan keperawatan. Jurnal Keperawatan Notokusumo, 4(1), 1-11. 
Putra, C. S. (2019). PERANAN TEKNOLOGI INFORMASI DALAM PELAYANAN KEPERAWATAN DI RUMAH SAKIT. Simtika, 2(3), 28-31.

PERSEPSI, S., \& EKARINI, N. L. P. DOKUMENTASI CATATAN KESEHATAN ELEKTRONIK (EHR) DALAM KEPERAWATAN.

Prasetyanto, D., \& Sukihananto, S. (2019). Penerapan Sistem Informasi Keperawatan Virtually Nursing Technologies in Nursing Education: Sebuah Tinjauan Literatur. Jurnal Penelitian Kesehatan" SUARA FORIKES"(Journal of Health Research" Forikes Voice"), 10(2), 135-138.

Simamora, R. (2009). Dokumentasi Proses Keperawatan.

Simamora, R. H., Purba, J. M., Bukit, E. K., \& Nurbaiti, N. (2019). Penguatan Peran Perawat Dalam Pelaksanaan Asuhan Keperawatan Melalui Pelatihan Layanan Prima. JPPM (Jurnal Pengabdian Dan Pemberdayaan Masyarakat), 3(1), 25-31

Syam, A. D. (2019). Manfaat dan Hambatan dalam Pelaksanaan Sistem Informasi Keperawatan. Jurnal Keperawatan Muhammadiyah, 4(2).

Tarigan, R., \& Handiyani, H. (2019). Manfaat Implementasi Dokumentasi Asuhan Keperawatan Berbasis Komputerisasi Dalam Meningkatkan Mutu Asuhan Keperawatan. Jurnal Ilmiah Kesehatan Pencerah, 8(2), 110-116.

Zaharany, T. A. (2019). PERKEMBANGAN ELEKTRONIK LOGBOOK KEPERAWATAN DI AREA PELAYAN KESEHATAN: LITERATUR REVIEW. Jurnal Surya, 11(03), 26-32. 